\title{
Effect of Propylthiouracil on Hepatic Microsomal Mixed Function Oxidase and Lipid Deposition in Broiler Chicks Fed Diets with Different Fat Content.
}

\author{
Shigeki Kobayashi, Yukio AkIBA ${ }^{1)}$, Kazuaki TaKahashi ${ }^{1)}$ \\ and Masaaki HoriguCHI ${ }^{1}$ \\ Faculty of Animal Science, Kitasato University, Towada-shi, \\ Aomori 034, Japan \\ ${ }^{1)}$ Department of Animal Science, Faculty of Agriculture, \\ Tohoku University, Sendai-shi 981, Japan
}

\begin{abstract}
The effect of antithyroid agent (propylthiouracil, PTU) on the growth and a mixed function oxidase system (MFO) in hepatic microsomes and the lipid deposition in the liver and adipose tissue was studied in broiler chicks fed a high carbohydrate (HC) or a high fat (HF) diet. Male broiler chicks at 14 day old were fed on $\mathrm{HC}$ or $\mathrm{HF}$ diet supplemented with $0,0.0075$ or $0.0150 \%$ of PTU for 10 days. Dietary fat content or feeding the diet containing $0.0075 \%$ PTU did not affect the feed intake and body weight gain, whereas feeding the diet containing $0.0150 \%$ PTU decreased those in chicks fed HC diet. PTU administration significantly increased weight of thyroid grands, liver lipid and abdominal fat contents, but decreased plasma thyroxine concentration regardless of the diet. The liver lipid content in chicks fed the HF diet was lower than those of chicks fed the HC diet at identical PTU levels, but the effect was not significant. The contents of cytochrome P-450 and b5 in the hepatic microsome in chicks fed the HF diet were greater than those fed the HC diet regardless of PTU supplementation. PTU administration increased cy tochrome $\mathrm{P}-450$ content in chicks fed the HF diet. The result suggested that the increase in dietary fat content improved growth retardation and excessive lipid deposition in broiler chicks induced by the feeding of PTU, and the effects might be, in part, associated with the activation of hepatic microsomal MFO system.
\end{abstract}

(Jpn. Poult. Sci., $31: 20-27,1994)$

Key words : propylthiouracil, dietary composition, microsomal mixed function oxidase, lipid deposition

\section{Introduction}

Administration of an antithyroid substance, propylthiouracil (PTU), induces excessive lipid deposition in the liver and increases plasma lipid concentration in growing chicks (Evans et al., 1962 : RAHeJA et al., 1971 : RAHEJA and LinscheER, 1978). PTU when given with a high carbohydrate diet, resulted in an enlargement of the thyroid gland, hyperlipidemia, growth retardation and hypertrophy of the liver with increased glycogen and triglycerides accumulation (RAHEJA et al., 1971 : RAHEJA and LINSCHEER, 1978). However, when the high carbohydrate $(\mathrm{HC})$ diet was replaced by the high fat (HF) diet, hypertrophy of the liver and increases in triglyceride and glycogen accumulation in the liver were not obvious (RAHEJA and LinscheER, 1978).

The mixed function oxidase (MFO) system is involved in the metabolism of drugs, xenobiotics (such as food additives, chemicals and pesticides), steroids, and fatty acids

Received Jun. 14, 1993 
(Campbell and Hayes, $1974: \mathrm{Lu}$ and Levin, 1974 : Pan and Fouts, 1978 : Keyes et al., 1979 : TAKAHASHI and JENSEN, 1984). This system is modified by the nutritional status (CAmpbell and Hayes, 1976 : W Ade and Norred, $1976: Z_{\text {Annoni }}$ and Sato, 1976). Hepatic microsomes of rats fed the $\mathrm{HF}$ diet have been shown to contain more cytochromes $\mathrm{P}-$ 450 than those of rats fed the fat-free diet (Yoo et al., 1990 : W ADE et al, 1985 : W ADE and NoRRED, 1976). Yoo et al (1991) reported that rats fed a diet with higher fat/carbohydrate ratio accompanied with the higher hepatic microsomal $\mathrm{P}-450$ content than those fed a diet with lower fat/carbohydrate ratio. These reports lead us to expect an assumption that the HF diet activates the MFO system in the liver, and consequently increases PTU metabolism and reduces the activation of PTU upon lipid deposition.

The purpose of the current study was to investigate the effect of PTU on MFO systm in male broiler chicks and to determine if variations in MFO system associated with changes in dietary composition are involved in the changes in lipid deposition in the liver and adipose tissue induced by PTU supplementation.

\section{Materials and Methods}

Sixty male broiler chicks (14 day old) were divided into 6 groups with 5 replicates of two chicks each and housed in wire cages under controlled light (14 hours light and 10 hours dark) and temperature $\left(24^{\circ} \mathrm{C}\right)$. They were fed ad libitum each of the HC diet or the HF diet (Table 1) which supplemented with $0,0.0075$ or $0.0150 \%$ PTU for 10 days. At the end of experimental period, blood was collected by cardiac puncture with a

Table 1. Composition of high carbohydrate (HC) and high fat (HF) diet (\%)

\begin{tabular}{lcc}
\hline \multicolumn{1}{c}{ Ingredients } & HC diet & HF diet \\
\hline Yellow corn & 73.60 & 39.66 \\
Soybean oil meal & 11.83 & 36.69 \\
Soybean protein & 9.50 & - \\
Soybean oil & 0.50 & 10.00 \\
Cellulose & - & 9.45 \\
L-Lysine $\mathrm{HCl}$ & 0.21 & 0.03 \\
DL-methionine & 0.31 & 0.33 \\
$\mathrm{~L}-\mathrm{Arginine}$ & 0.14 & - \\
$\mathrm{CaHPO} \cdot 2 \mathrm{H}_{2} \mathrm{O}$ & 1.81 & 1.79 \\
$\mathrm{CaCO}$ & 1.00 & 0.95 \\
$\mathrm{NaCl}$ & 0.31 & 0.30 \\
Vitamin mix & 0.40 & 0.40 \\
$\mathrm{Mineral} \mathrm{mix}{ }^{1)}$ & 0.40 & 0.40 \\
\hline $\mathrm{Calculated} \mathrm{values}$ & & \\
$\mathrm{CP}(\%)$ & 20.5 & 20.5 \\
$\mathrm{ME}(\mathrm{kcal} / \mathrm{kg})$ & 3,100 & 3,100 \\
$\mathrm{Ca}(\%)$ & 0.90 & 0.90 \\
$\mathrm{P}(\%)$ & 0.65 & 0.65 \\
$\mathrm{Available} \mathrm{P}(\%)$ & 0.45 & 0.45 \\
\hline
\end{tabular}

1) Aкiвa, Y. and T. Matsumoto (1978) 
heparinized syringe and centrifuged for 15 minutes at $1500 \times \mathrm{g}$. The plasma was stored for later analyses. The thyroid, liver and abdominal fat pad were removed to weigh.

Liver lipids were extracted by the method of Folć et al. (1957) and determined gravimetrically. Plasma concentration of thyroxine was determined by radioimmunoassay using commercial radioimmunoassay kit (Eiken Chemical Co., Japan). A portion of the livers was placed in a ice-cold $0.25 \mathrm{M}$ sucrose in $0.1 \mathrm{M}$ Tris-HC1 buffer. These livers were then provided for microsomal preparations as described by TAKAHASHI et al. (1991).

Cytochromes P-450 and cy tochrome b5 contents in the microsomes were measured by the procedure of OMURA and SATO (1964). The activities of NADPH-cytochrome $c$ reductase and $\mathrm{NADH}$-cytochrome b5 reductase were determined by the methods of Phillips and Landon (1962) and Takesue and Omura (1970), respectively. The protein content was determined using the protein assay kit (Bio Rad Co., USA).

Statistical Analysis

Significant differences among treatments were determined by Duncan's multiple range test (DUNCAN, 1955).

\section{Results}

Table 2 shows the effects of PTU on feed intake, body weight gain, feed efficiency, thyroid weight and plasma thyroxine concentration in male broiler chicks fed HC or HF diet. Feed intake of chicks on the HC diet was similar to those on the HF diet with or without $0.0075 \%$ PTU supplementation. The addition of $0.0150 \%$ PTU decreased feed intake in chicks fed the HC diet, but not in chicks fed the HF diet. Body weight gain and feed efficiency were lowered by $0.0150 \%$ PTU administration, but not different between $\mathrm{HC}$ and $\mathrm{HF}$ diets. Thyroid weight and plasma thyroxine concentration were not significantly affected by the diets. The addition of PTU increased significantly (P $<0.05)$ the thyrold weight, and decreased significantly $(\mathrm{P}<0.05)$ the plasma thyroxine

Table 2. Effect of propylthiouracil (PTU) on feed intake, body weight gain, feed efficiency,

\begin{tabular}{lccc}
\hline & \multicolumn{3}{c}{ HC diet } \\
\cline { 2 - 4 } PTU levels (\% in diet) & 0 & 0.0075 & 0.0150 \\
\hline Feed intake $^{1}(\mathrm{~g})$ & $758 \pm 20^{\mathrm{a}}$ & $746 \pm 13^{\mathrm{a}}$ & $685 \pm 6^{\mathrm{b}}$ \\
Body weight gain $^{2}(\mathrm{~g})$ & $483 \pm 27^{\mathrm{a}}$ & $459 \pm 19^{\mathrm{ab}}$ & $395 \pm 14^{\mathrm{b}}$ \\
Feed efficiency & $0.63 \pm 0.02^{\mathrm{a}}$ & $0.62 \pm 0.03^{\mathrm{a}}$ & $0.58 \pm 0.04^{\mathrm{ab}}$ \\
$\begin{array}{c}\text { Thyroid weight } \\
(\mathrm{mg} / 100 \text { body weight })^{\text {Plasma thyroxine }} \\
(\mu \mathrm{g} / 100 \mathrm{~m} l)\end{array}$ & $6.7 \pm 0.7^{\mathrm{c}}$ & $17.0 \pm 2.5^{\mathrm{a}}$ & $15.4 \pm 0.6^{\mathrm{ab}}$ \\
\hline
\end{tabular}

Abbreviations : HC, high carbohydrate ; HF, high fat.

${ }^{1}$ Mean \pm SE with 5 observations.

${ }^{2}$ Mean \pm SE with 10 observations.

Means having different superscripts within a line are significantly different at $\mathrm{P}<0.05$.

NS, not significant. * $\mathrm{P}<0.05$. $^{* *}, \mathrm{P}<0.01$. 
concentration.

Table 3 shows the changes of liver weight, mixed function oxidase system (MFO) in hepatic microsomes, liver lipid content and abdominal fat weight by feeding PTU. The liver weight of chicks fed the HC diet was similar to those fed the HF diet. The addition of PTU increased significantly $(\mathrm{P}<0.05)$ liver weights, and the extent of the increases was greater in chicks fed the HC diet than the HF diet. The liver lipid content and abdominal fat weight were not significantly affected by the differences in diets. The addition of PTU significantly increased the liver lipid content and abdominal fat weight. In chicks fed on the HF diet, liver lipid content and abdominal fat weight increased with an increase in PTU. The $0.0150 \%$ PTU decreased the hepatic microsomal protein content in chicks fed the $\mathrm{HC}$ diet, but increased in the HF diet. The contents of cytochrome $\mathrm{P}-450$ and b5 were increased in chicks fed the HF diet over those fed the HC diet with or without PTU supplementation. The addition of PTU increased significantly $(\mathrm{P}<0.01)$ the cytochrome $\mathrm{P}-450$ content in chicks fed the HF diets. The similar trend was observed in chicks fed the $\mathrm{HC}$ diet indicating that PTU increased the cytochrome $\mathrm{P}-450$. The activity of NADPH-cytochrome $\mathrm{c}$ reductase and $\mathrm{NADH}-\mathrm{cy}$ tochrome b5 reductase were not affected by the diets or the administration of PTU. The significant interactions between the effects of diet and PTU were found for the liver weight, abdominal fat weight, hepatic microsomal protein and cytochrome $\mathrm{P}-450$ content.

\section{Discussion}

Feeding an antithyroid drug reduced feed intake, and thereby lowered the body weight gain in chickens (Evans et al., 1962 : RAHEJA and LinscheER, 1978 : Akiba et al., 1983). In the present study, the supplementation of $0.0075 \%$ PTU had no effects on feed intake and body weight gain in male broiler chicks fed either $\mathrm{HC}$ or HF diet. Administration of PTU induces hypothyroidism and results in enlargement of the

thyroid weight and plasma thyroxine concentration in broiler chicks fed HC or HF diet

\begin{tabular}{|c|c|c|c|c|c|}
\hline \multicolumn{3}{|c|}{ HF diet } & \multicolumn{3}{|c|}{ Analysis of variance } \\
\hline 0 & 0.0075 & 0.0150 & Diet & PTU & Diet $\times$ PTU \\
\hline $722 \pm 26^{\mathrm{ab}}$ & $765 \pm 11^{\mathrm{a}}$ & $757 \pm 13^{a}$ & NS & NS & NS \\
\hline $432 \pm 27^{\mathrm{ab}}$ & $465 \pm 26^{\mathrm{ab}}$ & $419 \pm 19^{\mathrm{ab}}$ & NS & * & NS \\
\hline $0.62 \pm 0.01^{\mathrm{a}}$ & $0.61 \pm 0.03^{\mathrm{ab}}$ & $0.55 \pm 0.02^{\mathrm{b}}$ & NS & $*$ & NS \\
\hline $5.0 \pm 0.2^{c}$ & $18.5 \pm 1.2^{\mathrm{a}}$ & $12.2 \pm 1.2^{\mathrm{b}}$ & NS & $* *$ & NS \\
\hline $2.20 \pm 0.30^{\mathrm{a}}$ & $0.87 \pm 0.12^{\mathrm{b}}$ & $0.70 \pm 0.03^{\mathrm{b}}$ & NS & $* *$ & NS \\
\hline
\end{tabular}


Table 3. Effect of PTU on liver weight, liver lipid content, abdominal fat weight and

\begin{tabular}{|c|c|c|c|}
\hline \multirow[b]{2}{*}{ PTU levels (\% in diet) } & \multicolumn{3}{|c|}{$\mathrm{HC}$ diet } \\
\hline & 0 & 0.0075 & 0.0150 \\
\hline Liver weight (g/100 g BW) & $2.41 \pm 0.11^{\mathrm{d}}$ & $4.85 \pm 0.27^{\mathrm{a}}$ & $4.21 \pm 0.25^{\mathrm{ab}}$ \\
\hline Liver lipid (mg/liver) & $1,146 \pm 90^{\mathrm{b}}$ & $2,424 \pm 222^{\mathrm{a}}$ & $2,061 \pm 256^{\mathrm{a}}$ \\
\hline Abdominal fat weight $(\mathrm{g} / 100 \mathrm{~g} \mathrm{BW})$ & $1.19 \pm 0.07^{\mathrm{bc}}$ & $1.54 \pm 0.11^{\mathrm{ab}}$ & $1.53 \pm 0.10^{\mathrm{ab}}$ \\
\hline \multicolumn{4}{|l|}{ Microsomal : } \\
\hline Protein (mg/g liver) & $9.45 \pm 0.48^{\mathrm{ab}}$ & $9.48 \pm 0.47^{\mathrm{ab}}$ & $6.63 \pm 0.41^{\mathrm{c}}$ \\
\hline Cytochrome $\mathrm{P}-450^{1)}$ & $43.2 \pm 4.7^{\mathrm{b}}$ & $51.6 \pm 5.6^{\mathrm{b}}$ & $56.5 \pm 5.2^{\mathrm{b}}$ \\
\hline Cytochrome b5 $5^{1)}$ & $129 \pm 8^{b}$ & $162 \pm 17^{\mathrm{a}}$ & $125 \pm 11^{\mathrm{b}}$ \\
\hline NADPH-cy tochrome $c$ reductase ${ }^{2)}$ & $24.4 \pm 1.6$ & $22.4 \pm 2.7$ & $21.8 \pm 2.1$ \\
\hline NADH-cytochrome b5 reductase ${ }^{2)}$ & $435 \pm 50$ & $394 \pm 49$ & $372 \pm 29$ \\
\hline
\end{tabular}

Abbreviations : HC, high carbohydrate; HF, high fat.

Mean \pm SE with 6 observations.

Means having different superscripts within a line are significantly different at $\mathrm{P}<0.01$.

NS, not significant. ${ }^{*}, \mathrm{P}<0.05 .^{* *}, \mathrm{P}<0.01$.

${ }^{1} \mathrm{p}$ moles/mg microsomal protein.

${ }^{2} \mathrm{n}$ moles $/ \mathrm{min} / \mathrm{mg}$ microsomal protein.

thyroid gland, hyperlipidemia, and an excessive lipid deposition in livers of chickens (EvANs et al., 1962 : RAHEJA and LINSCHEER, 1978). Our data confirmed the above reports such that an administration of $0.0075 \%$ PTU for 10 days increased weight of thyroid gland, abdominal fat and liver weight, and content of liver lipid, and significantly reduced the plasma thyroxine concentration. In addition, our results indicated that the supplementation of PTU at the level of $0.0075 \%$ to diets might be effective to induce hypothyroidism and excessive lipid deposition without an adverse effects on the performance in male broiler chicks. The addition of $0.0150 \%$ PTU depressed feed intake and body weight gain in chicks fed the HC diet, but not in chicks fed the HF diet. The extents of increase in the liver weight and liver lipid deposition induced by 0.0075\% PTU supplementation were lower in chicks fed the HF diet as compared to those in chicks fed the HC diet. These results may indicate that the growth retardation and excessive liver lipid accumulation induced by the PTU feeding are ameliorated by an increase of dietary fat content and are in agreement with the results of RAHEJA and LiNSCHEER (1978). In addition, our experiment suggest that these effects of the dietary fat are independent of the changes in plasma thyroxine concentration. Dietary lipid was required for the synthesis of MFO components and the activity of cytochrome P-450 in the liver (Marshall and McLean, 1971 : Norred and Wade, 1972). The present study showed that the cytochrome P-450 and b5 contents in hepatic microsomes of chicks fed the HF diet without PTU were higher than those of chicks fed the $\mathrm{HC}$ diet. It has been established that the activities of microsomal MFO systems in rat livers increase as dietary fat levels increase (Yoo et al., 1991 : Yoo et al., 1990 : W ADE et al., 1986 : WADE and NORRED, 1976). Even when PTU was supplemented in diets, contents of cytochrome $\mathrm{P}-450$ and b5 were higher in chicks fed the HF diet than those fed the $\mathrm{HC}$ diet. In chicks fed the HF diet, the cytochrome P-450 content increased with the increase in PTU supplementation, but not in chicks fed the HC diet. Plasma 
hepatic microsomal mixed function oxidase systems in broiler chicks fed HC or HF diet

\begin{tabular}{|c|c|c|c|c|c|}
\hline \multicolumn{3}{|c|}{ HF diet } & \multicolumn{3}{|c|}{ Analysis of variance } \\
\hline 0 & 0.0075 & 0.0150 & Diet & PTU & Diet $\times$ PTU \\
\hline $2.50 \pm 0.10^{d}$ & $3.35 \pm 0.37^{\mathrm{c}}$ & $3.99 \pm 0.29^{\mathrm{bc}}$ & $*$ & $* *$ & $* *$ \\
\hline $998 \pm 52^{\mathrm{b}}$ & $1,699 \pm 345^{\mathrm{ab}}$ & $2,022 \pm 391^{\mathrm{a}}$ & NS & $* *$ & NS \\
\hline $0.99 \pm 0.10^{c}$ & $1.30 \pm 0.15^{\mathrm{bc}}$ & $1.83 \pm 0.15^{\mathrm{a}}$ & NS & $* *$ & $*$ \\
\hline $8.18 \pm 0.48^{b}$ & $9.25 \pm 0.41^{\mathrm{ab}}$ & $9.67 \pm 0.48^{\mathrm{a}}$ & NS & $*$ & $* *$ \\
\hline $71.7 \pm 11.1^{\mathrm{b}}$ & $145.8 \pm 17.0^{\mathrm{a}}$ & $175.0 \pm 16.6^{\mathrm{a}}$ & $* *$ & $* *$ & $* *$ \\
\hline $163 \pm 11^{\mathrm{a}}$ & $175 \pm 9^{\mathrm{a}}$ & $190 \pm 7^{\mathrm{a}}$ & $* *$ & NS & NS \\
\hline $20.4 \pm 0.9$ & $20.4 \pm 0.5$ & $21.8 \pm 0.8$ & NS & NS & NS \\
\hline $417 \pm 35$ & $492 \pm 40$ & $510 \pm 58$ & NS & NS & NS \\
\hline
\end{tabular}

thyroxine concentration is positively correlated with liver lipid deposition in laying hen (AкIBA et al., 1983). The increase of dietary fat content did not modify the decrease in plasma thyroxine concentration induced by PTU in this study. Thus the amelioration by the HF diet in the growth retardation and excessive lipid deposition in liver could not be interpreted by the changes in thyroid function, and thereby accounted for the activated MFO in chicks fed HF diet. TAKAHASHI and JENSEN (1984) demonstrated that the decrease in liver lipid deposition in laying hens and estrogen-implanted chicks accompanied with the activation of hepatic MFO system. The modification in growth retardation and excessive lipid deposition in the liver caused by the feeding of HF diet may therefore, at least in part, be ascribed to the activation of MFO system when PTU was added to the diets.

\section{References}

АкiвA, Y. and T. Mатsumoto (1978) Effects of force-feeding and dietary cellulose on liver lipid accumulation and lipid composition of liver and plasma in growing chicks. Journal of Nutrition, 108 : 739-748.

Akiba, Y., K. Takahashi, M. Kimura, S.-I. Hirama and T.Matsumoto (1983) The infuluence of environmental temperature, thyroid status and a synthetic estrogen on the induction of fatty livers in chicks. British Poultry Science, $24: 71-80$.

CAMPBELL, T.C. and J.R. HAYES (1974) Role of nutrition in the drug-metabolizing enzyme system. Pharmacological Reviews, 26 : 171-197.

CAMPBELL, T.C. and J.R. HAYES (1976) The effect of quantity and quality of dietary protein on drug metabolism. Federation Proceedings. $35: 2470-2474$.

DunCAN, D.B. (1955) Multiple range and multiple F-tests. Biometrics $11: 1-42$.

Evans, J.D., Buryk, N.O., Middleton, P.J. and H.G. Schwarts (1962) Effect of thyroid powder or propylthiouracil on chick liver and plasma lipids. Endocrinology $70: 465-470$.

Folch, J., M. Lees and G.H. Sloan-STANley (1957) A simple method for the isolation and purification of total lipids from animal tissues. Journal of Biological Chemistry, 226 : 497509. 
Keyes S.R., Alfano, J.A., Jansson, I. and D.I. Cinti (1979) Rat liver microsomal elongation of fatty acids. Journal of Biological Chemistry, 254 : 7778-7784.

LU, A.Y.H. and S. LEVIN (1974) The resolution and reconstitution of the liver microsomal hydroxylation. Biochimica et Biophysica Acta, 344 : 209-240.

MARShall, W.J. and A.E.M. MCLEAN (1971) A requirement for dietary lipids for induction of cy tochrome $\mathrm{P}-450$ by phenobarbitone in rat liver microsomal fraction. Biochemical Journal, $122: 569-573$.

Norred, W.P. and A.E. W AdE (1972) Dietary fatty acid-induced alteration of hepatic microsomal drug metabolism. Biochemical Pharmacology, 21 : 2287-2897.

Omura, T. and R. SATo (1964) The carbon monoxide-binding pigment of liver microsomes. Journal of Biological Chemistry, 239 : 2370-2378.

PAN, H.P. and J.R. FouTs (1978) Drug metabolism in birds. Drug Metabolism Reviews, 7 : 1-244.

PhILlips, A.H. and R.G. LANDON (1962) Hepatic triphosphopyridine nucleotide cytochrome c reductase : Isolation, characterization, and kinetic studies. Journal of Biological Chemistry, 237 : 2652-2660.

RAHEJA, K.L. and W.G. LinSCHEER (1978) Effect of dietary composition on liver glycogen accumulation and lipid metabolism in the hypothyroid chick (Gallus domesticus). Comparative Biochemistry and Physiology, 61 A : 31-34.

Raheja, K.L., Snedecor, J.G. and R.A. Freedland (1971) Effect of propylthiouracil feeding on glycogen metabolism and malic enzyme in the liver of the chick (Gallus domesticus). Comparative Biochemistry and Physiology, 39B : 833-842.

Takesue, S. and T. Omura (1970) Purification and properties of NADH-cytochrome b5 reductase solubilized by lysosomes from rat liver microsomes. Journal of Biological Chemistry, 267 : 267-276.

TAKAHASHI, K. and L.S. JENSEN (1984) Effect of dietary composition and estradiol implants on hepatic microsomal mixed function oxidase and lipid deposition in growing chicks. Poultry Science, 63 : 2217-2224.

Takahashi, K., H. Nishimura, Y. Akiba and M. Horiguchi (1991) Effect of stocking density and supplemental ascorbic acid on growth, organ weight, mixed function oxidase in hepatic microsomes, lipid metabolism and plasma corticosterone in male broiler chicks. Animal Science Technology (Jpn.), $62: 829-838$.

WADE, A.E. and W.P. NORRED (1976) Effect of dietary lipid on drug-metabolizing enzymes. Federation Proceedings, 35 : 2475-2479.

Wade, A.E. and White, R.A., Walton, L.C. and J.T. Bellows (1985)Dietary fat - a requirement for induction of mixed-function oxidase activities in starved-refed rats. Biochemical Pharmacology, $34: 3747-3754$.

Yoo, J.-S.H., Hong, J.-Y. NING, S.M. and C.S. YANG (1990) Roles of dietary corn oil in the regulation of cytochromes P450 and glutathione S-transferases in rat liver. Journal of Nutrition, 120 : 1718-1726.

Yoo, J.-S.H., Ning, S.M., PAntuck, C.B., Pantuck, E.J. and C.S. Yang (1991) Regulation of hepatic microsomal cytochrome P450IIE1 level by dietary lipids and carbohydrates in rats. Journal of Nutrition, 121 : 959-965.

Zannoni, V.G. and P.H. Sato (1976) The effect of certain vitamin deficiencies on hepatic drug metabolism. Federation Proceedings, 35 : 2464-2469. 


\title{
ブロイラーの肝臓ミクロソーム薬物代謝酵素活性と脂肪蓄積に対す る抗甲状腺物質投与と飼料中脂肪含量の影響
}

\author{
小林茂樹・秋葉征夫 ${ }^{1)} \cdot$ 高橋和昭 $^{1)} \cdot$ 堀口雅昭 ${ }^{1)}$ \\ 北里大学獣医畜産学部 十和田市 034 \\ 1)東北大学農学部 仙台市 981
}

抗甲状腺物質（プロピルチオウラシル，PTU）投与と 飼料中脂肪含量が, ブロイラーの成長, 肝臟ミクロソー ム薬物代謝酵素活性および脂肪蓄積に対する影響を検討 した。高炭水化物 $(\mathrm{HC})$ 飼料之高脂肪 $(\mathrm{HF})$ 飼料の両飼 料それぞれにPTUを $0,0.0075$ および $0.0150 \%$ 添加し た計 6 試験飼料を 14 日齢の雄ブロイラーに 10 日間給与 した。飼料摃取量および増体重に対する飼料組成あるい はPTU0.0075\% 添加の影響は見られなかったが，HC 飼 料にPTUを $0.0150 \%$ 添加するとこれらは減少した。甲 状腺重量, 肝臟脂質量および腹腔内脂肪量は飼料組成に 関係なくPTU 投与により增加し，血漿中サイロキシン 濃度は減少した。 HF 飼料にPTUを添加した時の肝臟
脂質量は $\mathrm{HC}$ 飼料に添加した時よりあ低かった。チトク ローム P-450 および b5 含量はPTU 添加の有無に関わ らず $\mathrm{HF}$ 飼料給与区の方が $\mathrm{HC}$ 飼料給与区より高かっ た。HF 飼料給与時のチトクローム P-450 含量は PTU の添加により増加した。

以上の結果から, PTU 給与によるブロイラーの成長 停滞之脂肪の過剩蓄積は高脂肪飼料の給与により改善さ れ, この改善効果には肝臓ミクロソーム薬物代謝酵素活 性が幾分関与していることが示唆された。

(家禽会誌, $31: 20-27,1994$ ) キーワード: プロピルチオウラシル, 飼料組成, ミクロ ソーム薬物代謝酵素, 脂肪蓄積 